\title{
Analisa Erosi dan Sedimentasi Berbasis Sistem Informasi Geografis (SIG) Pada Bagian Hulu Das Way Rarem Kabupaten Lampung Utara
}

\author{
M. Bobby Hartawan ${ }^{1 *}$, Ery Suhartanto ${ }^{1}$, Sri Wahyuni ${ }^{1}$ \\ ${ }^{1}$ Jurusan Teknik Pengairan, Fakultas Teknik, Universitas Brawijaya \\ Jl. MT. Haryono No. 167, Malang, 65145, Indonesia \\ * Korespodensi Email : muhammadbobby17@gmail.com
}

\begin{abstract}
This study aims to determine the amount of erosion rate in the Way Rarem sub-watershed and determine the sediment amount that enters the reservoir. All data processing processes obtained to determine the boundaries of the sub-watershed, the magnitude of the erosion rate, the level of erosion hazard, the level of criticality of the land, the level of land capability, and the direction of land-use change will be carried out with the help of GIS. The research show that, 1) the existing average erosion rate of 1560745.504 tonnes/year,(2)based on the simulation results of the scenario erosion rate using the Erosion Hazard Index (IBE) equation with a total area of 298.63 ha of watershed area, obtained five criteria with several levels of land criticality, 3) the area function in the Way Rarem watershed is a protected area, an area buffer and cultivation areas, conservation efforts carried out by constructing sediment control structure (check dam).4)sediment that enters the reservoir and the service life of the reservoir, it is planned that half the amount of sediment can be controlled in the upstream area of the reservoir. Various types of checkdam building have been taken according to SNI-2851.
\end{abstract}

Keywords: Check Dam, Erosion, Geographic Information Systems, Sediment

Abstrak: Penelitian ini bertujuan untuk mengetahui besarnya laju erosi pada Sub DAS Way Rarem dan mengetahui besar sedimen yang masuk ke waduk. Semua proses pengolahan data yang diperoleh untuk menentukan batasan Sub DAS, besarnya laju erosi, tingkat bahaya erosi, tingkat kekritisan lahan, tingkat kemampuan lahan, dan arahan perubahan tata guna lahan tersebut akan dilakukan dengan bantuan SIG. Hasil dari penelitian menunjukkan bahwa, 1) hasil kondisi eksisting rata - rata laju erosi 1560745.504 ton/tahun, 2) didapatkan 5 kriteria dengan beberapa tingkat kekritisan lahan, dan 3) fungsi kawasan pada DAS Way Rarem merupakan kawasan lindung, kawasan penyangga dan kawasan budidaya, usaha konservasi yang dilakukan dengan membangun bangunan pengendali sedimen (checkdam). 4) sedimen yang masuk ke waduk dan umur layanan waduk maka direncakan separuh dari jumlah sedimen bisa dikendalikan di daerah hulu waduk. Berbagai tipe perhitungan bangunan checkdam sudah diperhitungkan menurut SNI-2851.

Kata kunci: Bangunan Pengendali Sedimen, Erosi, Sedimen, Sistem Informasi Geografis 


\section{Pendahuluan}

DAS adalah suatu wilayah yang merupakan suatu wilayah daratan yang dibatasi oleh pemisah topografi dan berfungsi sebagai pengumpul, penyimpan dan juga penyalur air. Jika terjadi hujan di daerah tersebut, maka air hujan yang akan turun mengalir ke sungai-sungai yang ada disekitar daerah tersebut. Air yang berasal dari curah hujan tersebut akan mengalir dengan alaminya ke danau atau ke laut $[1,2]$.

Lokasi way rarem ini termasuk lokasi perencanaan pembangunan (MUSRENBANG) Tahun 20192024. Pelaksanaan musrenbang RKPD Kabupaten Lampung Utara merupakan bagian dari rangkaian proses perencanaan dengan pendekatan bottom up, yaitu dengan menjaring seluruh aspirasi masyarakat. Hal ini membuktikan komitmen seluruh jajaran pemerintah Kabupaten Lampung Utara melibatkan pertisipasi masyarakat dalam tahapan perencanaan pembangunan. Dalam hal ini SIG yang membantu untuk menentukan perhitungan limpasan permukaan, erosi dan hasil sedimen dengan metode USLE (Universal Soil Loss Equation) dan SIG untuk menduga besarnya laju rata-rata erosi tertentu pada suatu kecuraman lereng dengan pola hujan tertentu untuk setiap macam pertanaman dan tindakan pengelolaan di Das Way Rarem [3,4,5]. Penelitian ini bertujuan untuk mengetahui besarnya laju erosi yang terjadi pada Sub DAS Way Rarem berdasarkan metode USLE (Universal Soil Loss Equation), mengetahui kondisi tingkat bahaya erosi, tingkat kekritisan lahan, dan tingkat kemampuan lahan di Sub DAS Way Rarem, mendapatkan batasan Sub DAS Way Rarem beserta informasi mengenai tingkat bahaya erosi, dan mengetahui besar sedimen yang masuk ke waduk Way Rarem $[6,7,8]$.

\section{Bahan dan Metode}

\subsection{Bahan}

\section{A. Wilayah Studi}

Subjek pada penelitian ini adalah Waduk Way Rarem yang terletak di Desa Pekurun, Kecamatan Abung Barat, Kabupaten Lampung Utara, Propinsi Lampung. Waduk ini, terletak pada kordinat $4^{\circ} 55^{\prime} 32,10^{\prime \prime}$ LS dan $104^{\circ} 47^{\prime} 5,69^{\prime \prime} \mathrm{LT}$. Waduk Way Rarem ini dapat menampung air sebesar 72,4 juta m3. Kapasitas tampungan tersebut tidak semuanya dapat dimanfaatkan untuk memenuhi kebutuhan air di irigasi, namun hanya sebesar 56,9 juta $\mathrm{m}^{3}$ saja yang disebut sebagai tampungan efektif. Sedangkan kapasitas tampungan sebesar 15,5 juta m3 merupakan tampungan yang disediakan untuk memenuhi tampungan sedimen yang masuk ke dalam waduk tersebut. Gambar peta lokasi dari waduk yang dimaksud dapat dilihat di bawah ini.

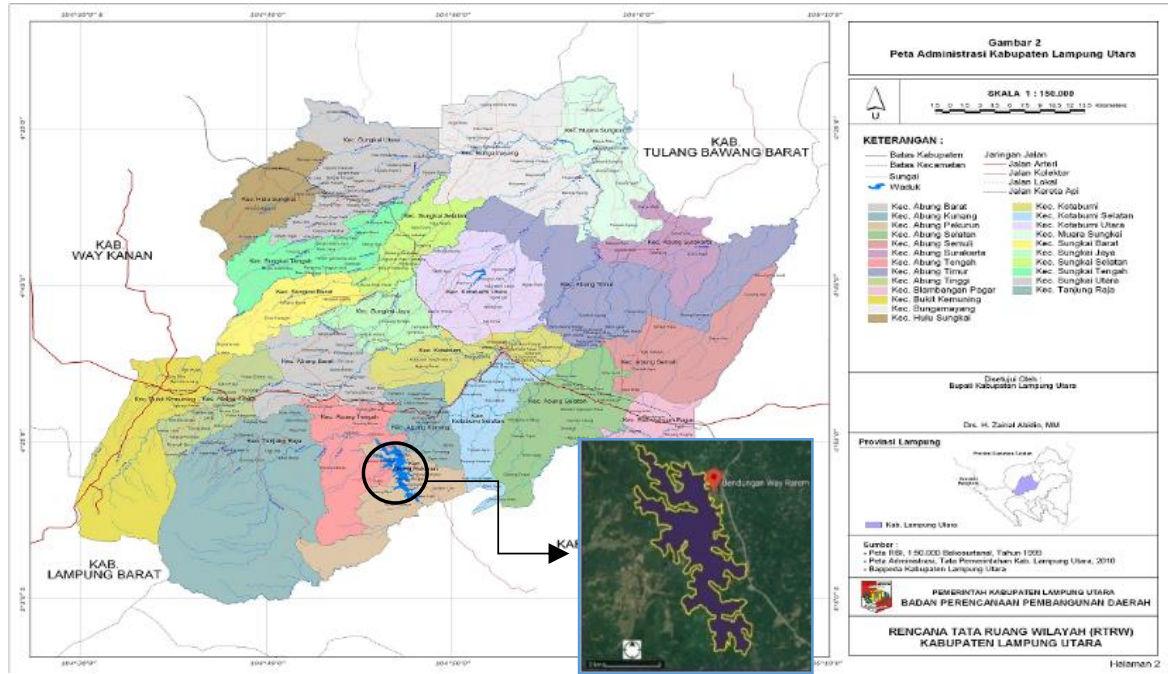

Sumber : Balai Besar Wilayah Sungai Mesuji-Sekampung, 2018

Gambar 1 : Peta Lokasi Waduk Way Rarem 
B. Data Penelitian yang Dibutuhkan

Dalam studi ini data yang mendukung dalam menyelesaikan studi ini :

1. Data curah hujan harian tahun $2009-2018$

2. Digital Elevation Model (DEM)

3. Tata Guna Lahan

4. Jenis Tanah

5. Administrasi

6. Jaringan Sungai (opsional)

\subsection{Metode}

Semua proses pengolahan data yang diperoleh untuk menentukan batasan Sub DAS, besarnya laju erosi, tingkat bahaya erosi, tingkat kemampuan lahan, arahan perubahan tata guna lahan tersebut akan dilakukan dengan bantuan SIG. Data yang sudah diinputkan ke dalam SIG baik itu data spasial maupun data non spasial telah menjadi beberapa file yang dapat diolah didalam SIG maupun. Sebelum melakukan proses pengolahan data berikutnya, terlebih dahulu dilakukan pembentukan topologi pada data spasial dengan perintah build dan clean.

Analisa Sistem Informasi Geografis yang dimaksud adalah melakukan tumpang susun (overlay) peta-peta spasial hasil dari penggabungan data-data spasial dan data-data atribut (Intersect). Dalam studi ini untuk melakukan overlay digunakan perintah geoprosesing dengan menggunakan SIG, Setelah terbentuk peta hasil Intersect, maka dapat melakukan analisa penentuan kriteria laju erosi,

tingkat bahaya erosi, kekritisan lahan, klasifikasi kemampuan lahan, serta analisa perubahan tata guna lahan berdasarkan ARLKT dengan SIG.

\section{Hasil dan Pembahasan}

\subsection{Perhitungan Erosi}

USLE (Universal Soil Loss Equation), faktor yang akan dihitung meliputi faktor erosivitas hujan $(\mathrm{R})$, faktor erodibilitas (K), faktor panjang dan kemiringan lereng (LS), dan faktor pengelolaan tanaman dan usaha pencegahan erosi (CP).

\section{A. Faktor Erosivitas (R)}

Data curah hujan yang digunakan untuk menghitung faktor erosivitas diperoleh dari data curah hujan di sub DAS Way Rarem. Karena sebaran data curah hujan yang diambil dari 3 stasiun.

Nilai R sebagai berikut contoh perhitungan Stasiun Kebon Tebu tahun 2018 Bulan Januari :

$\mathrm{Rm}=6,119 \times($ Rain $) \mathrm{m}^{1,21} \times($ Days $) \mathrm{m}^{0,47} \times\left(\right.$ Max P) $\mathrm{m}^{0,53}$

$\mathrm{Rm}=6,119 \times 0,178^{1,21} \times 16^{0,47} \times 0,65^{0,53}$

$\mathrm{Rm}=143,32$

Dan

$$
R=\sum_{m=1}^{12}(R m) \quad \text { Pers. } 1
$$

dengan $: \mathrm{R}=$ erosivitas curah hujan tahunan rata-rata $=$ jumlah $\mathrm{Rm}$ selama 12 bulan. Sebagai berikut contoh perhitungan Stasiun Kebon Tebu dari tahun 2009 - 2018 :

$\mathrm{R}=(1438,74+2596,54+1662,58+1995,48+3009,36+1891,08+1652,09+3547+2542,75+$ $1656,80) / 10=2201,94$ 
Tabel 1: Keterangan Faktor Erosivitas (R)

\begin{tabular}{ccccc}
\hline No. & Sta. Hujan & Nilai R & $\begin{array}{c}\text { Luas Area } \\
\left(\mathrm{Km}^{2}\right)\end{array}$ & Warna \\
\hline 1. & Kebon Tebu & 2201,94 & 6536,76 & Hijau Tua \\
2. & Subik & 2173,97 & 21715,7 & Cream \\
3. & Pekurun & 2587,33 & 1610,57 & Cream keputihan \\
\hline & Total & & 29863,03 & \\
\hline
\end{tabular}

B. Faktor Erodibilitas Tanah (K)

Faktor yang mempengaruhi tanah, antara lain : tekstur tanah, struktur tanah, permeabilitas dan bahan organik [6]. Berikut adalah Langkah untuk membuat peta Jenis tanah DAS Way Rarem:

1. Melakukan proses dijitasi peta tekstur/jenis tanah di Arcgis 10.3, dalam hal ini mendijit tata guna lahannya dan batas administrasi kecamatan.

2. Mengedit peta hasil dijitasi jika ada kesalahan pendijitasian.

3. Memasukkan data spasial dan atribut ke dalam Arcgis.

4. Meng clip peta jenis tanah dengan poligon daerah tangkapan hujan (Catchment Area) Waduk Way Rarem.

5. Menambahkan nilai indeks erodibilitas tanah pada peta jenis tanah

Peta jenis tanah Daerah Way Rarem ditunjukkan pada Gambar 2 [9]. Untuk lebih jelas tentang bentuk dari penggambaran peta kemiringan lahan DAS Way Rarem, bisa dilihat pada gambar 3.

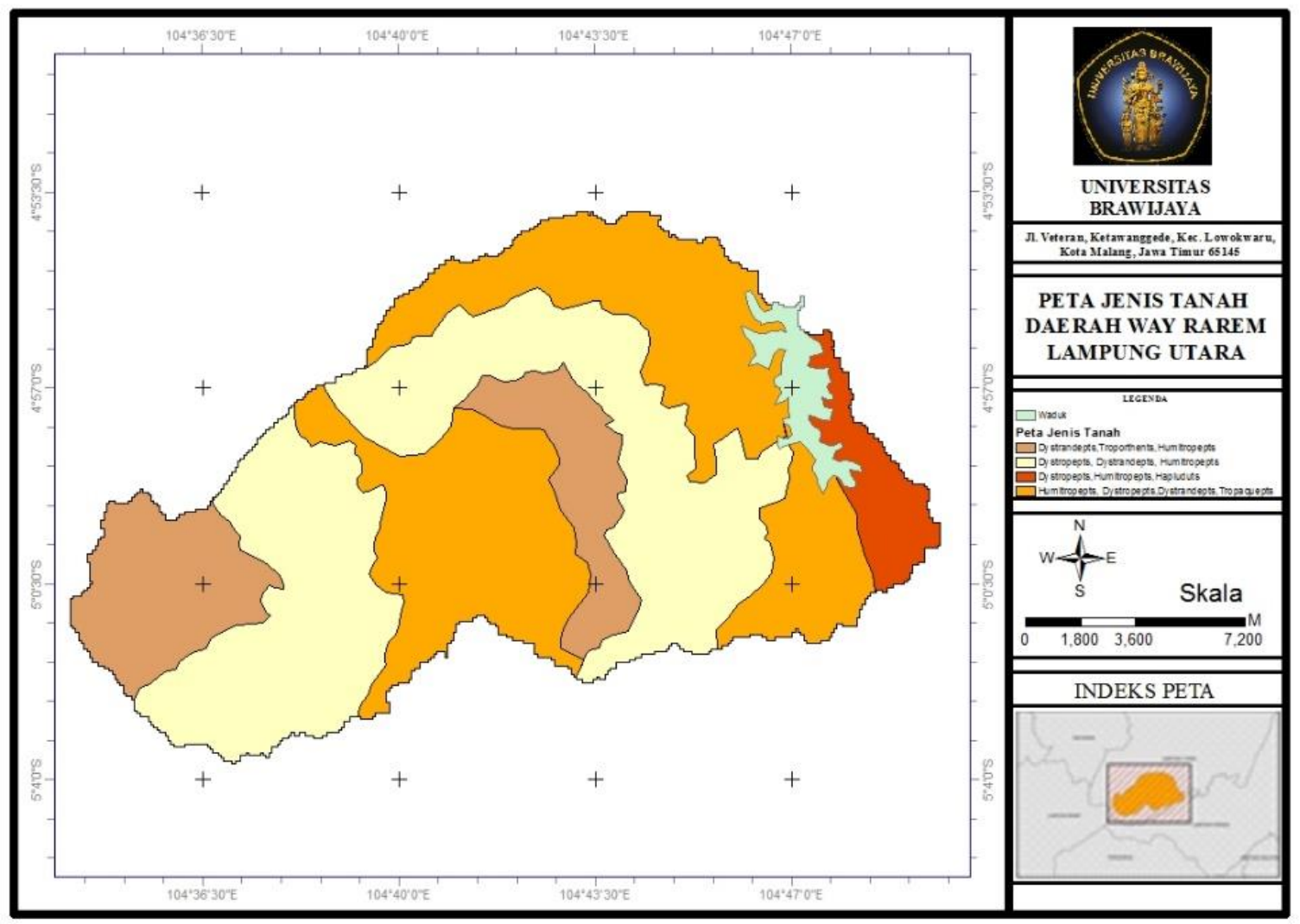

Gambar 1 : Peta Jenis Tanah

Dibawah ini menunjukkan tabel untuk hasil nilai K dan juga luasan untuk setiap wilayah masing masing. DAS Way Rarem ini saya mengambil data nilai $\mathrm{K}$ dari penelitian yang sudah dilakukan sebelumnya. 
Tabel 2: Keterangan Gambar Jenis Tanah (K)

\begin{tabular}{lllll}
\hline No. & Jenis Tanah & $\begin{array}{l}\text { Nilai } \\
\mathrm{K}\end{array}$ & $\begin{array}{l}\text { Luas } \\
\left(\mathrm{km}^{2}\right)\end{array}$ & Warna \\
\hline 1. & Dystrandepts, Troporthents, Humitropepts & 0,26 & 4775,91 & Coklat \\
2. & Dystropepts, Dystrandepts, Humitropepts & 0,26 & 11762,37 & Cream \\
3. & Dystropepts, Humitropepts, Hapluduts & 0,26 & 1691,18 & Merah Tua \\
4. & Humitropepts, Dystropepts, Dystrandepts, Tropaquepts & 0,26 & 11632,64 & Orange \\
\hline & Total & & 29862,1 & \\
\hline
\end{tabular}

Sumber : Parapto, tahun 2018 [2]

C. Faktor Panjang dan Kemiringan Lereng (LS)

Bentuk kemiringan dan Kelas kemiringan ditentukan berdasarkan peta kontur DAS Way Rarem yang diolah dengan ArcGis 10.3. Berdasarkan bentuk topografinya, areal DAS Way Rarem dikelompokan menjadi 5 kelas kemiringan (s) yaitu $0-8 \%, 8-15 \%, 15-25 \%, 25-45 \%$, dan > 45 $\%$. Gambar dan tabel berikut dibawah ini.

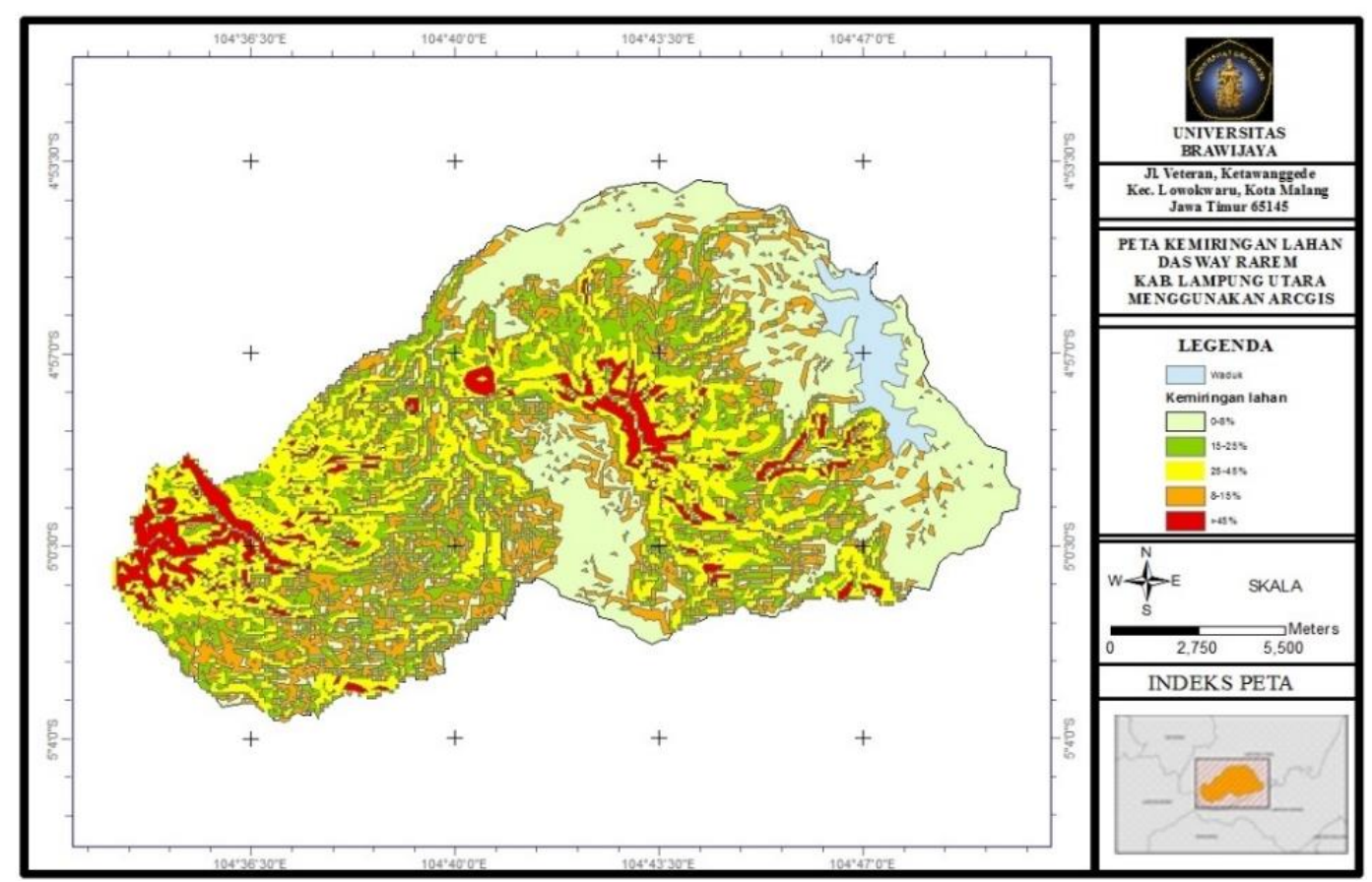

Gambar 2: Peta Kemiringan Lahan

Tabel 3: Klasifikasi Kemiringan Lahan (LS)

\begin{tabular}{cccccc}
\hline No. & $\begin{array}{c}\text { Kemiringan } \\
\text { Lahan }\end{array}$ & Klasifikasi & Nilai LS & Luas $\left(\mathrm{km}^{2}\right)$ & Warna \\
\hline 1. & $0-8 \%$ & Datar & 0,4 & 9596,36 & Hijau Muda \\
2. & $8-15 \%$ & Landai & 1,4 & 5735,33 & Hijau \\
3. & $15-25 \%$ & Agak Curam & 3,1 & 6396,85 & Kuning \\
4. & $25-45 \%$ & Curam & 6,8 & 6405,29 & Orange \\
5. & $45>$ & Sangat Curam & 9,5 & 1718,17 & Merah \\
\hline \multicolumn{5}{c}{ Total } \\
\hline
\end{tabular}

D. Faktor Pengelolaan Tanaman dan Usaha Pencegahan Erosi (CP)

Sebagai berikut adalah Langkah - Langkah untuk membuat peta tata guna lahan sub DAS Way Rarem. Dalam penggambaran peta tata guna lahan eksisting dibutuhkan peta topografi. Adapun tahapan dalam penggambaran peta tata guna lahan adalah sebagai berikut: 
1. Melakukan proses dijitasi peta tekstur tanah di Arcgis 10.3, dalam hal ini mendijit tata guna lahannya dan batas administrasi kecamatan.

2. Mengedit peta hasil dijitasi jika ada kesalahan pendijitasian.

3. Memasukkan data spasial dan atribut ke dalam Arcgis.

4. Analisa SIG dengan cara mengoverlay peta tata guna lahan dengan peta Sub DAS Way Rarem. Setiap kali selesai mengoverlay peta sebaiknya dianalisa dengan perintah:: pilih menu Xtools tekan sub menu Calculate Perimeter Area, dengan tujuan untuk mendapatkan nilai luasan poligon yang baru terbentuk.

5. Mereclassify sesuai peruntukannnya.

Adapun deskripsi eksisting di lokasi studi adalah sebagai berikut:

1. Hutan :hutan pinus dengan kerapatan rendah dan jarang/tidak ada seresah, banyak pohonpohon tumbang akibat penebangan liar dan pembukaan lahan untuk pemukiman

2. Kebun :banyak ditanami sayur-sayuran, jagung, kopi, lada dan sejenis kacang-kacangan.

3. Sawah :Tanah yang digarap dan diairi untuk tempat menanam padi.

4. Semak belukar, padang rumput/tanah kosong: intensitas penggunaan lahan sering digunakan untuk penggembalaan ternak.

Deskripsi tata guna lahan eksisting ini bermanfaat untuk analisa dan perhitungan selanjutnya serta memperjelas perbedaan antara tata guna lahan eksisting dan tata guna lahan setelah adanya ARLKT. Penggambaran peta tata guna lahan DAS Way Rarem, bisa dilihat pada gambar 5.

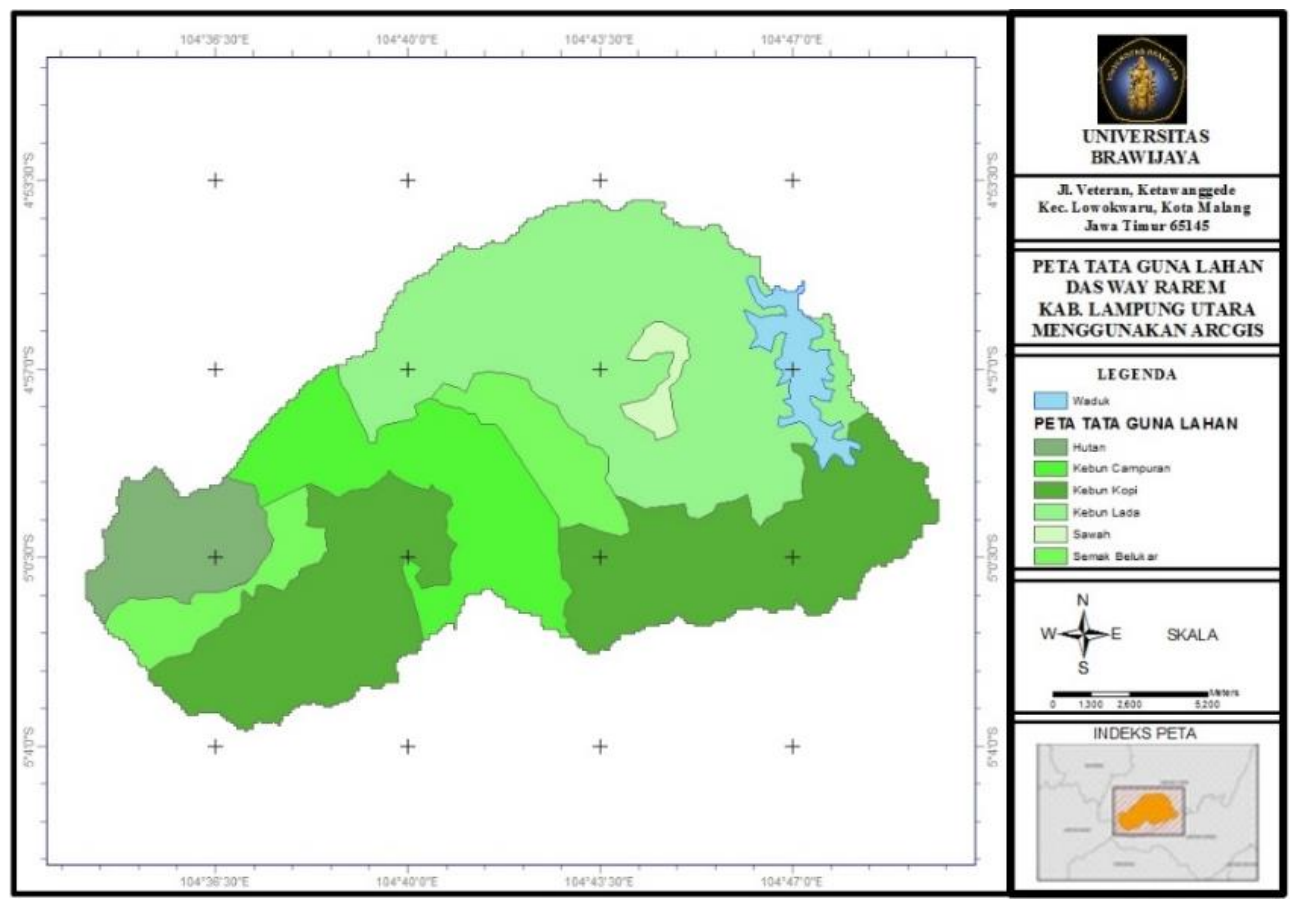

Gambar 4: Peta Tata Guna Lahan

Tabel 4: Keterangan Gambar Peta Tata Guna Lahan (CP)

\begin{tabular}{ccccc}
\hline No. & Tata Guna Lahan & Nilai CP & Luas $\left(\mathrm{km}^{2}\right)$ & Warna \\
\hline 1. & Hutan & 0,05 & 24,37 & Hijau Tua \\
2. & Kebun Campuran & 0,2 & 56,46 & Hijau Muda \\
3. & Kebun Kopi & 0,6 & 101,95 & Hijau Gelap \\
4. & Kebun Lada & 0,2 & 108,59 & Hijau sangat muda \\
5. & Sawah & 0,01 & 2,3 & Hijau Keputihan \\
6. & Semak Belukar & 0,1 & 32,2 & Hijau \\
\hline \multicolumn{7}{r}{} & Total & 234,86 & \\
\hline
\end{tabular}




\subsection{Analisis Laju Erosi}

Berdasarkan nilai dari faktor- faktor yang mempengaruhi besarnya erosi pada persamaan USLE, maka dapat dihitung perkiraan sebagai berikut :

$$
\begin{array}{ll}
\mathrm{A} & =\text { R.K.L.S.CP } \\
\mathrm{A} & =2201,94 \times 0,26 \times 0,4 \times 0,2 \\
\mathrm{~A} & =45,80 \text { ton/ha/tahun }
\end{array}
$$

Berdasarkan hasil perhitungan diatas maka perkiraan besarnya erosi yang terjadi adalah 45,80 ton/ha/tahun.

\section{A. Laju Erosi yang Diijinkan (TSL)}

Laju erosi yang dapat ditoleransikan didasarkan pada kedalaman solum tanah, permeabilitas tanah lapisan bawah, dan kondisi substratum. Berdasarkan kriteria Thompson, maka TSL di sub DAS Way Rarem adalah kelas 4 .dengan nilai $\mathrm{T}=8,96$ ton/ha/tahun.

\section{B. Analisa Indeks Bahaya Erosi}

Nilai perbandingan dari laju erosi dan yang diperbolehkan. Indeks bahaya erosi ini pada dasarnya bisa dihitung dengan nisbah dari laju erosi tanah potensial atau dapat disimbolkan dengan $A$ yang bersatuan ton/ha/tahun dengan laju erosi yang ditoleransi atau yang disimbolkan dengan TSLA yang bersatuan ton/ha/tahun. Atau dapat ditulis dengan rumus matematis berikut:

$$
I B E=\frac{A}{T S L} \quad \text { Pers. } 2
$$

IBE dapat diklasifikasikan menjadi 4 macam yakni IBE rendah, IBE tinggi, IBE sedang, dan IBE sangat tinggi. IBE tinggi menggambarkan kondisi lahan tidak baik atau kritis karena laju erosi lebih besar daripada nilai erosi yang bisa ditolerir [10]. Oleh karena itu, diperlukan rehabilitiasi lahan sebagai prioritas. Berikut gambar peta tingkat bahaya erosi IBE beserta keterangan tingkat kekritisan lahannya pada gambar 5 .

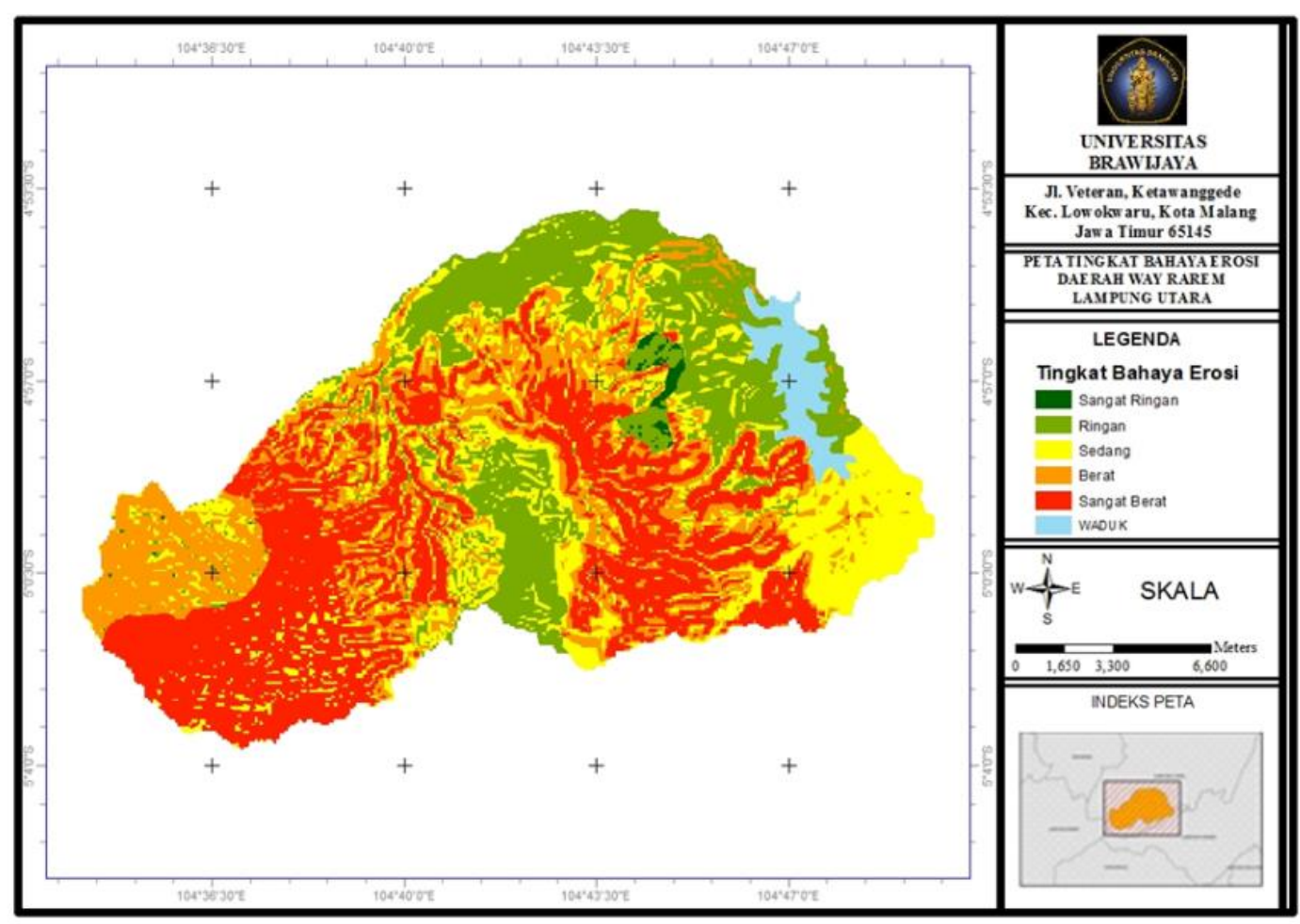

Gambar 3: Peta Indeks Bahaya Erosi 
Tingkat bahaya erosi sangat berat seluas 104,461 km2 (31,78\%), diikuti kelas bahaya erosi ringan seluas $92,262 \mathrm{~km} 2$ (28,07\%), berat seluas $89,998 \mathrm{~km} 2(27,38 \%)$, sedang seluas $38,856 \mathrm{~km} 2(11,82 \%)$, dan sangat ringan seluas $3,071 \mathrm{~km} 2(0,95 \%)$. Sedangkan untuk keterangan kelas dan luasnya bisa dilihat pada tabel dibawah ini.

Tabel 5: Analisis Indeks Bahaya Erosi

\begin{tabular}{cccc} 
No. & $\begin{array}{c}\text { Kelas TBE } \\
\text { (Class of erosion danger level) }\end{array}$ & $\begin{array}{c}\text { Kehilangan Tanah (Soil Loss) } \\
\text { (ton/ha/th) }\end{array}$ & Luas \\
\hline 1 & I & $<15$ & 146,7474 \\
2 & II & $16-60$ & 6151,742 \\
3 & III & $60-180$ & 6233,416 \\
4 & IV & $180-480$ & 6686,215 \\
5 & V & $>480$ & 9732,158 \\
& & Total & 28950,28 \\
\hline
\end{tabular}

3.3 Sedimentasi ke Waduk Way Rarem

A. Analisa Sedimen

Diketahui bahwa jumlah DAS yang ada di waduk way rarem berjumlah 5 yang masing masing mempunyai luas yang berbeda beda. Untuk menghitung besaran sedimen yang mengendap di dalam waduk dengan menggunakan hubungan antara SDR dan luas areal DAS. Hal itu Mengacu kepada tabel yang dikeluarkan oleh USDA Adapun Langkah - Langkah perhitungan untuk menganalisis sediment yang masuk ke waduk dapat diuraikan sebagai berikut:

1. Diketahui luas DAS Way Kelawas No.10 adalah 1971,92 ha.

2. Nilai SDR mengacu kepada tabel USDA dan pendekatan interpolasi didapatkan angka sebesar $0.204 \%$.

3. Sedimen yang masuk ke waduk dapat dihitung dengan rumus potensi erosi pertahun $\mathrm{x}$ dengan nilai SDR. Dalam hal ini erosi DAS Way Kelawas adalah 538238.723 m3/tahun x nilai SDR sebesar $0.204 \%=109650.172$ ton/tahun.

4. Untuk mendapatkan jumlah sediment yang masuk ke waduk maka nilai sediment 109650.172 ton/tahun $\mathrm{x}$ berat jenis tanah $(1.370)=80036.622$.

Untuk perhitungan sedimentasi yang masuk ke waduk pada DAS lainnya dapat dilihat pada tabel berikut:

Tabel 6 : Perhitungan Sedimentasi

\begin{tabular}{|c|c|c|c|c|c|c|}
\hline No. & Sub DAS & $\begin{array}{c}\text { Total laju } \\
\text { Erosi ton/th }\end{array}$ & $\begin{array}{l}\text { SDR } \\
(\%)\end{array}$ & $\begin{array}{c}\text { Total } \\
\text { Sedimentasi } \\
(\text { ton/th })\end{array}$ & $\begin{array}{c}\mathrm{BJ}(\mathbf{g}) \\
\text { (Ton/m3) }\end{array}$ & $\begin{array}{c}\text { Total } \\
\text { sedimentasi } \\
(\mathrm{m} 3 / \mathrm{th})\end{array}$ \\
\hline 1 & Way Galing 1 & 47013,869 & 0,301 & 14146,181 & 1,370 & 10325,679 \\
\hline 2 & Way Galing & 126624,323 & 0,261 & 33104,931 & 1,370 & 24164,183 \\
\hline 3 & Way Galing & 142561,603 & 0,282 & 40134,867 & 1,370 & 29295,523 \\
\hline 4 & Way Galing & 2927,357 & 0,379 & 1110,570 & 1,370 & 810,635 \\
\hline 5 & Way Galing & 2292,555 & 0,403 & 924,318 & 1,370 & 674,685 \\
\hline 6 & Way Kelawas & 1413,455 & 0,470 & 664,011 & 1,370 & 484,680 \\
\hline 7 & Way Kelawas & 18,890 & 0,636 & 12,010 & 1,370 & 8,767 \\
\hline 8 & $\begin{array}{c}\text { Way Campang Kanan } \\
\text { Way Campang Kiri } \\
\text { Way Tanjung Beringin } \\
\text { Way Kabu Batang }\end{array}$ & \multirow[t]{2}{*}{18137,115} & \multirow[t]{2}{*}{0,117} & \multirow[t]{2}{*}{1465746,444} & \multirow[t]{2}{*}{1,370} & \multirow[t]{2}{*}{1069887,915} \\
\hline 9 & Way Tanjung Balak & & & & & \\
\hline 11 & Way Kelawas & 626365,237 & 0,205 & 128360,634 & 1,370 & 93693,893 \\
\hline 12 & Way Galing & 596002,645 & 0,222 & 132038,193 & 1,370 & 96378,243 \\
\hline 13 & Way Galing & 3473668,798 & 0,158 & 548485,214 & 1,370 & 400354,170 \\
\hline
\end{tabular}


Untuk selanjutnya berbagai tipe checkdam akan ditabelkan seperti pada tabel berikut:

Tabel 7 : Perhitungan Bangunan Checkdam

\begin{tabular}{cccc}
\hline No. & Lebar sungai (B) & Tinggi As Bendung $(\mathrm{H})$ & Tampungan Checkdam $\mathrm{m}^{3}$ \\
\hline 1 & 15 & 10 & 22727.27 \\
2 & 20 & 15 & 45454.55 \\
3 & 25 & 20 & 75757.58 \\
4 & 30 & 25 & 113636.36 \\
5 & 35 & 30 & 159090.91 \\
\hline
\end{tabular}

Dari jumlah sedimen yang masuk ke waduk maka direncakan dari jumlah sedimen bisa dikendalikan di daerah hulu waduk dengan adanya bangunan pengendali sedimen. Sehingga hal itu akan memperpanjang umur layanan waduk.

\section{Kesimpulan}

Penelitian ini bertujuan untuk mengetahui besarnya laju erosi yang terjadi pada Sub DAS Way Rarem berdasarkan metode USLE (Universal Soil Loss Equation), mengetahui kondisi tingkat bahaya erosi, tingkat kekritisan lahan, dan tingkat kemampuan lahan di Sub DAS Way Rarem, mendapatkan batasan Sub DAS Way Rarem beserta informasi mengenai tingkat bahaya erosi, dan mengetahui besar sedimen yang masuk ke waduk Way Rarem.

Disimpulkan bahwa aplikasi Sistem Informasi Geografi didapatkan hasil kondisi eksisting rerata laju erosi 1560745.504 ton/tahun, hasil simulasi laju erosi skenario dengan menggunakan persamaan Indeks Bahaya Erosi (IBE) dan Tingkat Kekritisan Lahan dengan luas total DAS 298,63 ha, didapatkan 5 kriteria dengan beberapa tingkat kekritisan lahan, yaitu, kriteria sangat ringan (Potensial Kritis) sebesar 146.747 ha $(0.51 \%)$, kriteria ringan (Semi Kritis) sebesar 6151.741 ha $(21.25 \%)$, kriteria sedang (Kritis) sebesar 6233.416 ha (21.53\%), kriteria berat (super kritis) sebesar 6686.214 ha (23.10\%), dan kriteria sangat berat (super kritis) sebesar 9732.157 ha (33.62\%). Arahan Rehablitasi Lahan dan Konservasi Tanah (ARLKT) dengan pendekatan arahan fungsi kawasan menunjukkan bahwa fungsi kawasan pada Sub DAS Way Rarem merupakan kawasan lindung $426844 \mathrm{~km}^{2}$ (14,3\%), kawasan penyangga $531296 \mathrm{~km}^{2}(17,8 \%)$ dan kawasan budidaya $2021356 \mathrm{~km}^{2}(67,8 \%)$. Mengacu kepada jumlah sedimen yang masuk ke waduk maka direncakan separuh dari jumlah sedimen bisa dikendalikan di daerah hulu waduk. Berbagai tipe perhitungan bangunan checkdam sudah diperhitungkan menurut SNI-2851.

\section{Daftar Pustaka}

[1] M. Bisri, Pengelolaan DAS, Malang: CV. Asrori Malang, 2009.

[2] C. Asdak, Hidrologi dan Pengelolaan Daerah Aliran Sungai, Yogyakarta: Gadjah Mada University Press, 2010.

[3] D. Priambodo, E. Suhartanto and S. Sumiadi, "Analysis of Runoff Curve Number Distribution into Surface Runoff of Lesti Watershed," Civil and Environmental Science Journal (Civense), vol. 4, no. 1 , pp. $62-75$.

[4] S. Eryanto, U. Andawayanti and E. Suhartanto, "Analysis of Sedimentation for The Optimization of Lempake Dam Operations for Flood Control for The City of Samarinda, Province of East Kalimantan," Civil and Environmental Science Journal (Civense), vol. 4, no. 1, pp. 10-21. 
[5] S. E. Edison, M. Bisri and E. Suhartanto, "Studi teknologi konservasi untuk menurunkan laju erosi pada Sub DAS Sombe Lewara Provinsi Sulawesi Tengah," Jurnal Teknik Pengairan: Journal of Water Resources Engineering, vol. 3, no. 2, pp. 204-210.

[6] E. Wolok, E. Suhartanto and D. Harisuseno, "Studi Tingkat Kekritisan Lahan Sebagai Dasar Arahan Rehabilitasi Hutan Dan Lahan Das Marisa Di Kabupaten Pohuwato Provinsi Gorontalo," Jurnal Teknik Pengairan: Journal of Water Resources Engineering, vol. 5, no. 1, pp. 119-129.

[7] Y. Wardani, E. Suhartanto and R. Haribowo, "Analysis of The Correlation Between Land Use Changes in Sub Watershed Wuno Toward Lifetime of Wuno Reservoir, Sigi District, Central Sulawesi Province," Civil and Environmental Science Journal , vol. 2, no. 1, pp. 1-14.

[8] M. E. Yulianti, L. M. Limantara, E. Suhartanto and V. Dermawan, "odel of rainfall erosion index for predicting the potential erosion rate by using a rainfall simulator," IOP Conference Series: Earth and Environmental Science, vol. 437, no. 1, pp. 12-45.

[9] Suprapto, Aniesa Rinny Asnaning, "Prediksi tingkat bahaya erosi daerah tangkapan hujan waduk Way Rarem Propinsi Lampung,” Jurnal Ilmiah Teknik Pertanian, vol. 7, no.3, pp. 144 - 212. 2015.

[10] Hammer, W.I.1981. Second Soil Consevation Consultant Report. Journal of Centre For Soil Research. AGOVINS/78/006.-Tech.Note No.10 Bogor Indonesia 